Cite this: J. Mater. Chem. A, 2013, 1, 1018

Received 2nd November 2012 Accepted 23rd November 2012

DOI: $10.1039 / c 2 t a 00955 b$

www.rsc.org/MaterialsA

\section{The reaction between Nafion sulfonyl fluoride precursor membrane and 1,4-dimethylpiperazine does not yield reliable anion-exchange membranest}

\author{
Donna M. Hillman, Susan H. Stephens, Simon D. Poynton, Sam Murphy, Ai Lien Ong \\ and John R. Varcoe*
}

Recent reports that the reaction between Nafion sulfonyl fluoride precursor and the cyclic diamine 1,4-dimethylpiperazine yields stable anion-exchange membranes appear to be premature. On aqueous work up, membranes with high cation-exchange capacities and zero anion-exchange capacities are produced.

There is currently a significant level of research involving the development of alkaline polymer electrolyte fuel cells (APEFC) containing alkaline anion-exchange membranes (AAEM). ${ }^{1}$ Prior AAEM studies involve either the investigation of different polymer backbones $^{2}$ or different functional anion-exchange head-groups. ${ }^{3}$ Studies into soluble alkaline ionomers for membrane electrode assembly fabrication are also intensifying. ${ }^{4}$

There have been two recent reports of the development of anionexchange membranes (AEM) based on Nafion perfluorinated membranes. ${ }^{5,6}$ Both of these prior studies involve the reaction of Nafion ${ }^{\circledR}$ sulfonyl fluoride $\left(-\mathrm{SO}_{2} \mathrm{~F}\right)$ precursor membrane (Nafion$\mathbf{S O}_{2} \mathrm{~F}$ ) with the diamine 1,4-dimethylpiperazine (14DMP) (Scheme 1). The first communication on this system was in 2011 by Ramani et $a l^{5}{ }^{5}$ where Nafion ${ }^{\circledR}-111$ sulfonyl fluoride membrane (Dupont, $c a$. $30 \mu \mathrm{m}$ thickness) was reacted with $14 \mathrm{DMP}$ at $60^{\circ} \mathrm{C}$ for up to $24 \mathrm{~h}$ with a subsequent $\mathrm{OH}^{-}$anion-exchange process; they compared the Nafion-based AEMs [Nafion-DMP( $\left.\left(\mathbf{O H}^{-}\right)\right]$to polysulfone AEMs. A more recent 2012 report was published by Elabd $e t$ al. ${ }^{6}$ who reacted Nafion- $\mathbf{S O}_{2} \mathbf{F}$ membranes (111P, Ion Power, $25 \mu \mathrm{m}$ thickness) with 14DMP at room temperature for $3 \mathrm{~h}$ followed by a subsequent $\mathrm{OH}^{-}$ anion-exchange process. Both studies used infrared spectroscopic, water uptake and conductivity measurements to characterise the membranes; measurements such as ion-exchange capacity determinations (IEC), thermogravimetry, small angle X-ray scattering and fuel cell testing were also conducted. Note: Elabd et al. have also

Department of Chemistry, Faculty of Engineering and Physical Sciences, University of Surrey, Guildford GU2 7XH, UK. E-mail: j.varcoe@surrey.ac.uk; Tel: +44 (0)1483 686838

$†$ Electronic supplementary information (ESI) available: Additional details on the syntheses and titrations used and additional spectroscopic results (Raman, FTIR and solid state NMR). See DOI: 10.1039/c2ta00955b published a follow up paper on Nafion-based AEMs with different head-group chemistries. ${ }^{7}$

The Nafion-DMP( $\left(\mathrm{OH}^{-}\right)$produced by Ramani et al. ${ }^{5}$ yielded ion conductivities of over $45 \mathrm{mS} \mathrm{cm}{ }^{-1}\left(40 \mathrm{mS} \mathrm{cm} \mathrm{cm}^{-1}\right.$ for Nafion$\left.\operatorname{DMP}\left(\mathbf{C O}_{3}{ }^{2-}\right)\right)$ at $70{ }^{\circ} \mathrm{C}$, but they only referred to the theoretical cation-exchange capacity (CEC) of Nafion- $\mathbf{S O}_{3} \mathbf{H}\left(0.91\right.$ meq. $\mathrm{g}^{-1}=$ 1100 equivalent weight) and they did not determine the IEC directly. However, some of the data presented in these prior studies did not correlate well with the proposed synthesis of the AEM. For example, the Nafion-DMP( $\left(\mathbf{O H}^{-}\right)$produced by Elabd et al. ${ }^{6}$ yielded conductivities up to $5 \mathrm{mS} \mathrm{cm}^{-1}$ at $50{ }^{\circ} \mathrm{C}$. Unexpectedly, the conductivities at $50{ }^{\circ} \mathrm{C}$ for $\mathbf{N a f i o n}-\mathbf{D M P}\left(\mathbf{H C O}_{3}{ }^{-}\right)$,

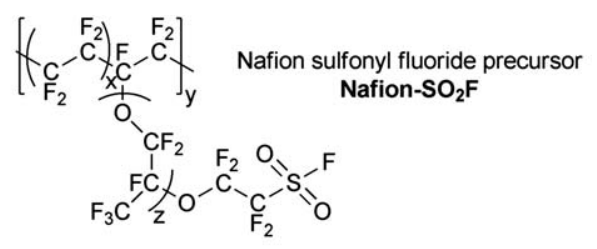<smiles>CN1CCN(C)CC1</smiles><smiles>O=S(=O)([O-])C(F)(F)F</smiles>

Nafion proton-exchange membrane Nafion- $\mathrm{SO}_{3} \mathrm{H}$ (PEM)
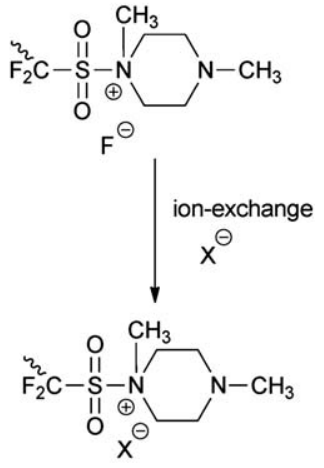

Nafion-DMP(X) ("AEM")
Scheme 1 The proposed reaction of Nafion ${ }^{\circledR}$ sulfonyl precursor [Nafion-SO ${ }_{2} \mathbf{F}$ ] with 1,4-dimethylpiperazine [14DMP] to form an AEM in $\mathrm{X}^{-}$anion form [Nafion$\operatorname{DMP}(\mathbf{X})$ ]. Also shown is the process to generate the standard PEM form of Nafion ${ }^{\circledR}\left[\right.$ Nafion- $\left.\mathbf{S O}_{3} \mathbf{H}\right] . \mathbf{X}=$ anion being studied. 
Nafion-DMP( $\left(\mathrm{CO}_{3}{ }^{2-}\right)$, and Nafion-DMP( $\left(\mathbf{C l}^{-}\right)$were higher at 7, 7, and $12 \mathrm{mS} \mathrm{cm} \mathrm{cm}^{-1}$ respectively. Could this be evidence of AEM degradation at high pHs in these prior studies? Additionally, the prior determined IECs [measured using the Warder back-titration technique, which yields the anion-exchange capacities (AEC)] were $\leq 0.1$ meq. $\mathrm{g}^{-1}$; these values are $<13 \%$ of the theoretical AEC value of 0.81 meq. $\mathrm{g}^{-1}$ (calculated from the mono-reaction of 14DMP with Nafion- $\mathbf{S O}_{2} \mathbf{F}$ as in Scheme 1). These very low AEC values then translated to the unexpectedly high reported $\lambda$ values (mol $\mathrm{H}_{2} \mathrm{O}$ molecules per mol anion $\mathrm{X}^{-}$).

The results reported in this communication detail experiments that investigate this intriguing system further. To complement the prior studies, we focused on characterising the membranes using vibrational spectroscopy, solid state NMR, and IEC methods.

All Nafion-DMP( $\left.\mathbf{F}^{-}\right)$syntheses followed the exemplar procedure detailed in the ESI ${ }^{\dagger}$ but with variations in Nafion- $\mathrm{SO}_{2} \mathrm{~F}+$ 14DMP reaction times $(3-503 \mathrm{~h}$ ) and temperatures (room temperature, $60{ }^{\circ} \mathrm{C}$ and $80{ }^{\circ} \mathrm{C}$ ). Work up involved removal of excess 14DMP, washing with water, and then storage in water until required. Despite washing with water, a continuous smell of 14DMP could still be detected from the vessels containing the reacted transparent brown membranes in their storage water over long periods of time (even with multiple replacement of the storage water). The membranes' colour also faded on prolonged exposure to water.

Ion-exchange of the as-synthesised Nafion-DMP( $\left.\mathbf{F}^{-}\right)$ membranes, into to the various other anion forms, were conducted by immersion of the membranes in excess aqueous solutions (at least $1 \mathrm{~mol} \mathrm{dm}^{-3}$ concentrations) for at least 1 day followed by soaking over at least 1 day in $18.2 \mathrm{M} \Omega \mathrm{cm}$ water. Despite this, the continuous presence of traces of $\mathrm{F}^{-}$anions (even after multiple changes of water) was observed using ion-chromatography of the post-exchange water washings; this tentative observation may suggest either the slow decomposition of the Nafion-DMP(X) AEM or the slow reaction of residual $-\mathrm{SO}_{2} \mathrm{~F}$ groups in the aqueous environment (potentially slightly alkaline considering the presence of amine groups).

Before the Raman spectra of select Nafion-DMP(X) AEMs can be investigated, the Raman spectrum of the starting material (and the potential cation-exchange byproduct) needs to be studied. Fig. S1 in the ESI $\dagger$ gives the FT-Raman spectra of Nafion- $\mathbf{S O}_{2} \mathbf{F}$ and the commercially available Nafion ${ }^{\circledR}-117$ proton-exchange membrane (Nafion-SO ${ }_{3} \mathbf{H}$ in Scheme $1, \mathrm{EW}=1100 \mathrm{~g} \mathrm{eq}^{-1}, 0.007$ inch in thickness, Alfa Aesar UK). The FT-Raman spectrum of Nafion- $\mathbf{S O}_{2} \mathbf{F}$ has bands at 1470, 1250, and $648 \mathrm{~cm}^{-1}$, that are well demarcated and not present in the spectrum of $\mathbf{N a f i o n}-\mathbf{S O}_{3} \mathbf{H}$; these are therefore diagnostic of the $-\mathrm{SO}_{2} \mathrm{~F}$ functional group. A band at $1470 \mathrm{~cm}^{-1}$ in the FTIR spectrum of Nafion- $\mathbf{S O}_{2} \mathbf{F}$ was tentatively assigned to the $\mathrm{S}-\mathrm{F}$ bond motion in a recent prior study ${ }^{8}$ and to the asymmetric $-\mathrm{SO}_{2}$ - stretch (of the $-\mathrm{SO}_{2} \mathrm{~F}$ group) in an earlier prior study. ${ }^{9}$ The Raman spectrum of Nafion- $\mathbf{S O}_{3} \mathbf{H}$ is well assigned (Table 2 in ref. 10). For example, the medium intensity band at $1060 \mathrm{~cm}^{-1}$ is due to the symmetrical $-\mathrm{SO}_{3}{ }^{-}$stretch, while the medium intensity band at $973 \mathrm{~cm}^{-1}$ is due to the symmetrical C-O-C stretch.

Fig. 1 below shows how the Raman spectra develop starting with Nafion- $\mathbf{S O}_{2} \mathbf{F}$ and then Nafion-DMP( $\left.\mathbf{F}^{-}\right)$membranes synthesised using increasing room temperature reaction times. First consider the disappearance of the $-\mathrm{SO}_{2} \mathrm{~F}$ related band at $1250 \mathrm{~cm}^{-1}$ and note

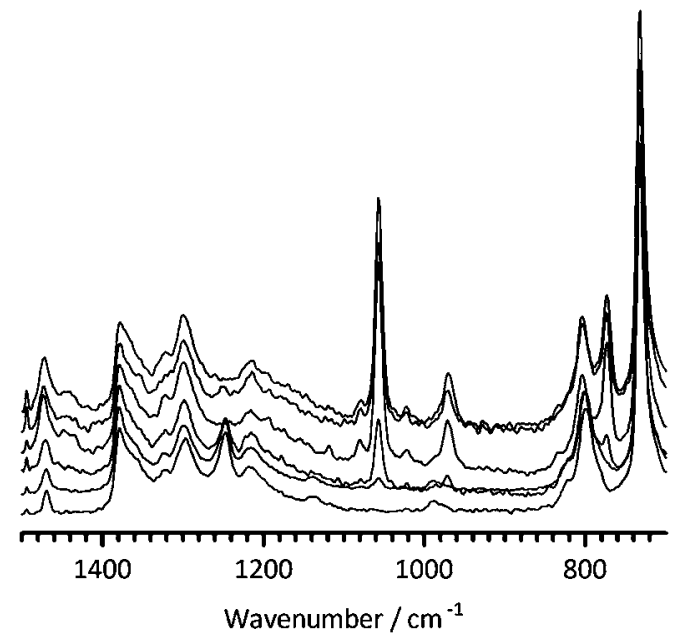

Fig. 1 The FT-Raman spectra (diagnostic region $1500-700 \mathrm{~cm}^{-1}$ ) of the Nafion$\mathbf{D M P}\left(\mathbf{F}^{-}\right)$membranes formed on the reaction of Nafion- $\mathbf{S O}_{\mathbf{2}} \mathbf{F}$ and $\mathbf{1 4 D M P}$ at room temperature for (from bottom to top): 0 h (i.e. pristine Nafion-SO $\mathbf{S}_{\mathbf{2}} \mathbf{F}$ ), $3 \mathrm{~h}$, $24 \mathrm{~h}, 100 \mathrm{~h}, 144 \mathrm{~h}$, and $196 \mathrm{~h}$. Spectra were normalised to the band at $1380 \mathrm{~cm}^{-1}$ and then stacked for clarity of presentation.

that Elabd et al. used $3 \mathrm{~h}$ reaction time with $25 \mu \mathrm{m}$ thick Nafion$\mathbf{S O}_{2} \mathbf{F}$ precursor membranes to synthesise their membranes. With the [thicker] $50 \mu \mathrm{m}$ Nafion- $\mathbf{S O}_{2} \mathbf{F}$ precursor membranes used in this study, $3 \mathrm{~h}$ is not adequate for reaction at room temperature as this band remains visible until $100+\mathrm{h}$ of reaction time. This is backed up by the gradual appearance of bands at 1057, 972 and $774 \mathrm{~cm}^{-1}$, all of which plateau in intensity after $c a .100 \mathrm{~h}$ of room temperature reaction time; the $\mathrm{SO}_{2} \mathrm{~F}$-related band at $1470 \mathrm{~cm}^{-1}$ in Nafion- $\mathbf{S O}_{2} \mathbf{F}$ also appears to increase in intensity on increasing reaction time. A C-H stretch band at $2980 \mathrm{~cm}^{-1}$ (not shown) also develops and plateaus in intensity around $100 \mathrm{~h}$ reaction time (the most intense $\mathrm{C}-\mathrm{H}$ stretch for in the spectrum of 14DMP is located at $2950 \mathrm{~cm}^{-1}$ see $\mathrm{ESI}+$ ). Solid state NMR Data (see ESI $\dagger$ ) yields further evidence of reaction of the $-\mathrm{SO}_{2} \mathrm{~F}$ functional group of the Nafion- $\mathbf{S O}_{2} \mathbf{F}$ precursor (this time with a Nafion-DMP( $\left(\mathbf{F}^{-}\right)$synthesised at $80{ }^{\circ} \mathrm{C}$ and $240 \mathrm{~h}$ ).

The Raman spectra of the different Nafion-DMP( $\left(\mathbf{F}^{-}\right)$ membranes are complex. The bands at 1057 and $972 \mathrm{~cm}^{-1}$ that develop on reaction are also present in the spectrum of Nafion$\mathbf{S O}_{3} \mathbf{H}$, but the new band at $774 \mathrm{~cm}^{-1}$ is absent from both the spectra of Nafion- $\mathbf{S O}_{3} \mathbf{H}$ and Nafion-$-\mathbf{S O}_{2} \mathbf{F}$; however, there is a strong band at $779 \mathrm{~cm}^{-1}$ in the spectrum of pristine 14DMP [there is also a medium intensity band at $1470 \mathrm{~cm}^{-1}$ in the Raman spectrum of 14DMP]. The bands located in the range $1051-1059 \mathrm{~cm}^{-1}$ in the FTIR spectrum of the Nafion-DMP(F $\left.\mathbf{F}^{-}\right)$and Nafion-DMP(OH produced in the prior study by Elabd et al. ${ }^{6}$ were assigned to the $-\mathrm{SO}_{2}-\mathrm{N}^{+} \mathrm{R}_{3}$ group. However, considering the spectroscopic data discussed above, this assignment is risky.

An alternative hypothesis is that there is a reaction [or partial reaction] between the 14DMP and $\mathbf{N a f i o n}-\mathbf{S O}_{2} \mathbf{F}$ but the product membranes [or residual $-\mathrm{SO}_{2} \mathrm{~F}$ groups in the membranes] react with the water [in the aqueous work up and in the presence of the alkaline piperazine-related groups] and form the proton-exchange form Nafion- $\mathbf{S O}_{3} \mathbf{H}$ membranes. The infrared spectroscopic data 
presented in the ESI $\dagger$ provides evidence of degradation of a Nafion$\mathbf{D M P}\left(\mathbf{F}^{-}\right)$membrane when exposed to alkaline conditions.

Fig. 2 shows an AEC curve ( $\mathrm{Cl}^{-}$method $)^{11}$ of an example Nafion$\operatorname{DMP}\left(\mathbf{C l}^{-}\right)$AEM. It is immediately obvious that the $\mathrm{Cl}^{-}$AEC cannot be determined as the release of $\mathrm{Cl}^{-}$is below the detection limit of the technique (and well below expected from the theoretical AEC of 0.81 meq. $\left.\mathrm{g}^{-1}\right)$. This was consistently the case for $\mathbf{N a f i o n}-\mathbf{D M P}\left(\mathbf{C l}^{-}\right)$ membranes synthesised with different reaction times and temperatures [Nafion-DMP( $\left.\mathbf{C l}^{-}\right)$membranes made from reactions at room temperature for $144-503 \mathrm{~h}$, at $80{ }^{\circ} \mathrm{C}$ for $240 \mathrm{~h}$, and $60{ }^{\circ} \mathrm{C}$ for 25 days were tested for AEC]. Zero ion-exchange capacities were also measured when the pre-titration $\mathrm{KCl}$ exchange solution were replaced with aqueous $\mathrm{HCl}\left(1 \mathrm{~mol} \mathrm{dm}^{-3}\right)$ [theoretically this modified titration method would enable the $\mathrm{Cl}^{-}$titrations to probe for the presence of non-ionic tertiary amine groups in addition to the ionic quaternary ammonium groups].

AEMs containing the $-\mathrm{SO}_{2}-\mathrm{N}\left(\mathrm{R}^{\prime}\right)-\mathrm{R}-\mathrm{N}^{+} \mathrm{R}_{3}{ }^{\prime \prime}$ functional group chemistry (where the $\mathrm{N}$ connected to the $-\mathrm{SO}_{2}-$ group is not charged) are known, ${ }^{12}$ but there is little precedence for the functional group $-\mathrm{SO}_{2}-\mathrm{N}^{+} \mathrm{R}_{3}$ (1-methyl-1-[(4-methylphenyl)sulfonyl]pyrrolidinium is a rare example on ChemSpider $\left.{ }^{13}\right)$. The question really must be - How stable is the $\mathrm{S}-\mathrm{N}$ bond in the proposed $-\mathrm{SO}_{2}-\mathrm{N}^{+}$ functional group in Scheme 1? To test this, the Nafion-DMP( $\left(\mathbf{F}^{-}\right)$ AEM [synthesised at room temperature and $144 \mathrm{~h}$ ] was tested for CEC (see ESI $\dagger$ for the standard method used): CEC $=0.79 \pm 0.08$ meq. $\mathrm{g}^{-1}$ (sd, $\left.n=3\right)$. As a control experiment, Nafion- $\mathbf{S O}_{2} \mathbf{F}$ was hydrolyzed in a solution of $15 \%$ mass $\mathrm{KOH}, 35 \%$ mass DMSO, and $50 \%$ mass de-ionized water at $80{ }^{\circ} \mathrm{C}$ for several hours, followed by thorough washing in water and final conversion to the $\mathrm{H}^{+}$form Nafion- $\mathrm{SO}_{3} \mathbf{H}$ membrane by immersion in nitric acid; the CEC of this control membrane $=0.92 \pm 0.05$ meq. $\mathrm{g}^{-1}$ (sd, $n=3$ ), which compares well to the theoretical 0.91 meq. $\mathrm{g}^{-1}$ for $\mathbf{N a f i o n}-\mathrm{SO}_{3} \mathbf{H}$

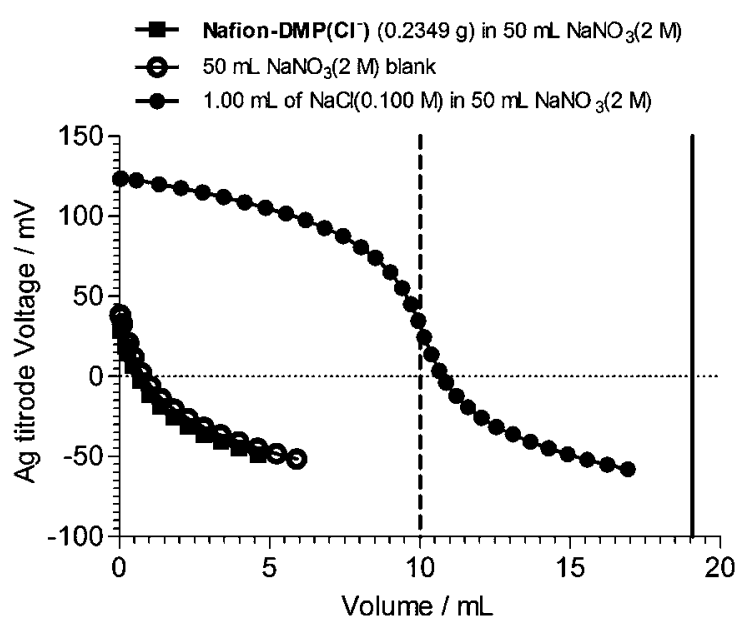

Fig. 2 The anion-exchange capacity (AEC) titration curves of a NafionDMP(Cl- ${ }^{-}$AEM synthesized from Nafion-SO ${ }_{2} \mathbf{F}$ and $\mathbf{1 4 D M P}$ at room temperature and $503 \mathrm{~h}$. The method used determines the amount of $\mathrm{Cl}^{-}$anions released from the AEM on immersion in excess $\mathrm{NaNO}_{3}\left(2 \mathrm{~mol} \mathrm{dm}^{-3}\right)$. The solid vertical line indicates the expected end point for $0.2349 \mathrm{~g}$ of AEM with the theoretical AEC of 0.81 meq. $\left.\mathrm{g}^{-1}\right)$. The dashed vertical line gives the theoretical endpoint for an aqueous solution consisting of $1.00 \mathrm{~cm}^{3}$ of $\mathrm{NaCl}\left(0.1000 \mathrm{~mol} \mathrm{dm} \mathrm{m}^{-3}\right)$ added to 50 $\mathrm{cm}^{3} \mathrm{NaNO}_{3}\left(2.0 \mathrm{~mol} \mathrm{dm}{ }^{-3}\right)$ which matches the actual control experiment conducted. membranes produced from Nafion ${ }^{\circledR}$ PFSA R-1100 sulfonyl fluoride precursor. This is very strong evidence that the end result of the synthesis procedure reported is membranes that are predominantly in the cation-exchange form. These membranes will therefore not be suitable for application in electrochemical devices requiring anionexchange polymer electrolytes (i.e. APEFCs and alkaline electrolysers).

The authors thank the UK's Engineering \& Physical Sciences Research Council (EPSRC grant EP/H025340/1 and Dr John Varcoe's EPSRC Leadership Fellowship funded with grant EP/I004882/1), the University of Surrey (for funds for Susan Stephen's final year undergraduate project) and the EPSRC Solid State NMR service at the University of Durham.

\section{References}

1 E. H. Yu, X. Wang, U. Krewer, L. Li and K. Scott, Energy Environ. Sci., 2012, 5, 5668; J. Pan, C. Chen, L. Zhuang and J. Lu, Acc. Chem. Res., 2012, 45, 473; G. Merle, M. Wessling and K. Nijmeijer, J. Membr. Sci., 2011, 377, 1; R. Zeng and J. R. Varcoe, Recent Pat. Chem. Eng., 2011, 4, 93; G. Couture, A. Alaaeddine, F. Boschet and B. Ameduri, Prog. Polym. Sci., 2011, 36, 1521; B. Pivovar, Alkaline Membrane Fuel Cell Workshop Final Report NREL/BK-560054297, National Renewable Energy Laboratory, Golden CO, USA, 2011, http://www.osti.gov/bridge; E. Antolini and E. R. Gonzalez, J. Power Sources, 2010, 195, 3431; S. Lu, J. Pan, A. Huang, L. Zhuang and J. Lu, Proc. Natl. Acad. Sci. U. S. A., 2008, 105, 20611; L. A. Adams, S. D. Poynton, C. Tamain, R. C. T. Slade and J. R. Varcoe, ChemSusChem, 2008, 1, 79.

2 N. J. Robertson, H. A. Kostalik IV, T. J. Clark, P. F. Mutolo, H. D. Abruña and G. W. Coates, J. Am. Chem. Soc., 2010, 132, 3400; M. R. Hibbs, C. H. Fujimoto and C. J. Cornelius, Macromolecules, 2009, 42, 8316; J. R. Varcoe, R. C. T. Slade, E. Lam How Yee, S. D. Poynton, D. J. Driscoll and D. C. Apperley, Chem. Mater., 2007, 19, 2686.

3 O. D. Thomas, K. J. W. Soo, T. J. Peckham, M. P. Kulkarni and S. Holdcroft, J. Am. Chem. Soc., 2012, 134, 10753; Y. Zha, M. L. Disabb-Miller, Z. D. Johnson, M. A. Hickner and G. N. Tew, J. Am. Chem. Soc., 2012, 134, 4493; S. Gu, J. Skovgard and Y. S. Yan, ChemSusChem, 2012, 5, 843; X. Lin, L. Wu, Y. Liu, A. L. Ong, S. D. Poynton, J. R. Varcoe and T. Xu, J. Power Sources, 2012, 217, 373; X. Wang, M. Li, B. T. Golding, M. Sadeghi, Y. Cao, E. H. Yu and K. Scott, Int. J. Hydrogen Energy, 2011, 36, 1002; Y. Ye and Y. A. Elabd, Macromolecules, 2011, 44, 8494; S. Gu, R. Cai and Y. Yan, Chem. Commun., 2011, 47, 2856; Q. Zhang, S. Li and S. Zhang, Chem. Commun., 2010, 46, 7495; X. Kong, K. Wadhwa, J. G. Verkade and K. Schmidt-Rohr, Macromolecules, 2009, 42, 1659; R. Schwesinger, R. Link, P. Wenzl, S. Kossek and M. Keller, Chem.-Eur. J., 2006, 12, 429; M. Tomoi, K. Yamaguchi, R. Ando, Y. Kantake, Y. Aosaki and H. Kubota, J. Appl. Polym. Sci., 1997, 64, 1161; K. J. T. Noonan, K. M. Hugar, H. A. Kostalik IV, E. B. Lobkovsky, H. D. Abruña and G. W. Coates, J. Am. Chem. Soc., 2012, 134, 18161. 
4 R. Zeng, J. Handsel, S. D. Poynton, A. J. Roberts, R. C. T. Slade, H. Herman, D. C. Apperley and J. R. Varcoe, Energy Environ. Sci., 2011, 4, 4925; M. Tanaka, M. Koike, K. Miyatake and M. Watanabe, Polym. Chem., 2011, 2, 99; W. Li, J. Fang, M. Lv, C. Chen, X. Chi, Y. Yang and Y. Zhang, J. Mater. Chem., 2011, 21, 11340.

5 M.-S. J. Jung, C. G. Arges and V. Ramani, J. Mater. Chem., 2011, 21, 6158.

6 H. L. S. Salerno, F. L. Beyer and Y. A. Elabd, J. Polym. Sci., Part B: Polym. Phys., 2012, 50, 552.

7 H. L. S. Salerno and Y. A. Elabd, J. Appl. Polym. Sci., 2013, 127, 298.
8 S. A. Perusich, J. Appl. Polym. Sci., 2011, 120, 165.

9 A. J. Greso, R. B. Moore, K. M. Cable, W. L. Jarrett and K. A. Mauritz, Polymer, 1997, 38, 1345.

10 A. Gruger, A. Régis, T. Schmatko and P. Colomban, Vib. Spectrosc., 2001, 26, 215.

11 O. I. Deavin, S. Murphy, A. Ong, S. D. Poynton, R. Zeng, H. Herman and J. R. Varcoe, Energy Environ. Sci., 2012, 5, 8584.

12 R. Ei Moussaoui and R. Martin, Eur. Pat. EP1612874, 2004; R. Ei Moussaoui and R. Martin, PCT Pat. WO2006003182, 2006.

$13 \mathrm{http}: /$ www.chemspider.com/Chemical-Structure.3526107.html, (accessed 15:39, 14 September 2012) [CSID: 3526107]. 